\title{
Adaptations of the Motor System in Animal Models of Spinal Cord Injury and Disuse
}

\author{
Pierre A. Guertin \\ Laval University $\mathcal{E}$ Laval University Medical Center \\ Canada
}

\section{Introduction}

More than 1.3 million patients are currently living with a spinal cord injury (SCI) in North America (Reeve Foundation). There is no cure for SCI although recent advances in acute care interventions (e.g., removal of bone fragments, decompression, anti-inflammatory drugs) have increased survival and reduced neurological dysfunctions (Baptiste \& Fehlings, 2007). Accordingly with the American Spinal Injury Association (ASIA) guideline, tetraplegic (cervical lesions) and paraplegic (thoracic lesions or below) patients are classified either as ASIA-A, ASIA-B, ASIA-C or ASIA-D (see Table 1). Quadriplegia also called tetraplegia is when a person has a SCI within the cervical area which results in paralysis of all four limbs. In addition to the arms and legs being paralyzed, the abdominal and chest muscles will also be affected which result in weakened breathing and the inability to properly cough and clear the chest. Paraplegia is when the level of injury occurs at the thoracic level or lower. Although they typically experience leg movement and abdomen problems, paraplegics can use their arms and hands.

\begin{tabular}{|l|l|}
\hline ASIA-A & No voluntary motor control and no sensation below injury level \\
\hline ASIA-B & No voluntary motor control, some sensations below injury level \\
\hline ASIA-C & Some motor control (< grade 3) and some sensations below injury level \\
\hline ASIA-D & Some motor control (> grade 3) and some sensations below injury level \\
\hline ASIA-E & Normal voluntary motor control and sensation below injury level \\
\hline
\end{tabular}

Table 1. Classification of SCI severity

Advanced rehabilitation 'activity-based' strategies such as body weight-supported treadmill training or BWSTT (leg movements generated passively by manual assistance from therapists) and functional electrical stimulation (FES)-biking are increasingly used especially with motorincomplete (ASIA-C and ASIA-D) patients. Indeed, given that spared descending pathways exist and, thus, some voluntary motor control remains in these subclasses of patients, it becomes possible to further increase voluntary ambulation using BWSTT training (Dobkin et al., 2006; Hicks \& Ginis, 2008). However, motor system, metabolic outcomes or health benefits associated with these approaches remain unclear (Hicks \& Ginis, 2008; Duffell et al., 2009). In turn, chronic SCI patients classified as motor-complete (ASIA-A \& ASIA-B) generally experience greater health problems often referred to as 'secondary complications' that are 
associated with significant changes of the motor, locomotor, skeletal, cardiovascular, circulatory and hematologic problems (Huang \& DeVivo, 1990; Bauman, 1999; Riegger et al., 2009; Rouleau et al., 2010,2011; Spungen, 2003). No safe, effective and regulatory agencyapproved treatments against these chronic problems exist yet.

In the last few years, great therapeutic hopes for motor-complete SCI patients (ASIA-A and ASIA-B) have emerged from physical activity-based studies performed in adult complete paraplegic cats showing that basic locomotor movements (i.e., hindlimb stepping) can be restored partially with regular treadmill training, weight support, passively generated movement and administration (i.t. or i.p.) of drugs such as clonidine, an alpha-2 noradrenergic agonist (Barbeau et al., 1993; Chau et al., 1998). Regular assisted training combined with clonidine and a few other monoaminergic drugs have even induced, in some cases, episodes of overground walking with Canadian crutches in previously wheelchairbound SCI patients (Barbeau et al., 1998). Clear evidence suggests that clonidine can, in fact, facilitate walking through reflex-mediated actions by decreasing spinal reflexes and hence spasticity and clonus (Waindberg et al., 1990; Remy-Neris et al., 1999). Unfortunately, at doses used for locomotor enhancement in some paraplegic patients, clonidine was also found to induce severe side effects even if given i.t. (i.e., bradycardia, sedation, hypotension - pers.com. Dr. Hugues Barbeau). It had therefore become imperative to identify other pharmacological strategies and compounds that could safely and more specifically enhance locomotor function recovery or reduce motor system changes and problems in chronic and, if possible, in motor-complete SCI patients (i.e., for whom BWSTT or other comparable approach does not yield beneficial effects). The identification of therapeutic approaches aimed at reducing or preventing motor system alterations in SCI or comparable chronic conditions (e.g., burn patients, AIDS patient with cachexia, etc.) would benefit both patients and health care systems for which associated costs are significant (approximately $\$ 100,000$ 400,000 per year/patient, Table 2).

\begin{tabular}{|l|l|}
\hline Initial hospitalization & $\$ 140,000$ \\
\hline $1^{\text {st }}$ year paraplegics & $\$ 152,000$ \\
\hline $1^{\text {st }}$ year tetraplegics & $\$ 417,000$ \\
\hline Averaged life time paraplegics & $\$ 428,000$ \\
\hline Averaged life time tetraplegics & $\$ 1,350,000$ \\
\hline
\end{tabular}

Table 2. Costs of SCI in U.S. dollars (source: http:/ / www.sci-info-pages.com/facts.html)

Although, these therapeutic approaches may not be designed to repair or cure SCI, they would nonetheless contribute at preventing (in acutely injured patients), reducing or reversing (in chronic SCI patients) secondary complications associated with motor system changes and significantly reduced physical activity (see also section 2.6).

\section{Motor system changes associated with spinal cord injury and disuse}

The motor system may be divided into several organs and structures. There is the central nervous system (CNS) that comprises the brain and the spinal cord. Its one hundred billion neurons are involved in motor and sensory functions (Kandel et al., 2000). The brain consists of the pyramidal and extrapyramidal system specifically associated with voluntary motor control. These brain structures constitute the main command centres that control voluntary 
muscular contraction. Most of their neuronal commands are sent to neurons and motoneurons located in the spinal cord where sensory motor integration and final motor commands sent to muscle are organized for proper induction of coordinated movements. In contrast, locomotion and other rhythmic and partially involuntary motor behaviours are largely controlled by signals and neuronal commands generated in the brainstem and spinal cord. In fact, complex neuronal circuits located in these non-cortical areas of the CNS are known to be capable of generating motor functions even in absence of descending inputs from cortical areas and other brain regions (Guertin \& Steuer, 2009; Guertin, 2010). In fact, locomotion, micturition, ejaculation, scratching, erection, and respiration are amongst the motor behaviours that are mainly controlled by spinal cord and brainstem circuits (see Fig.1).

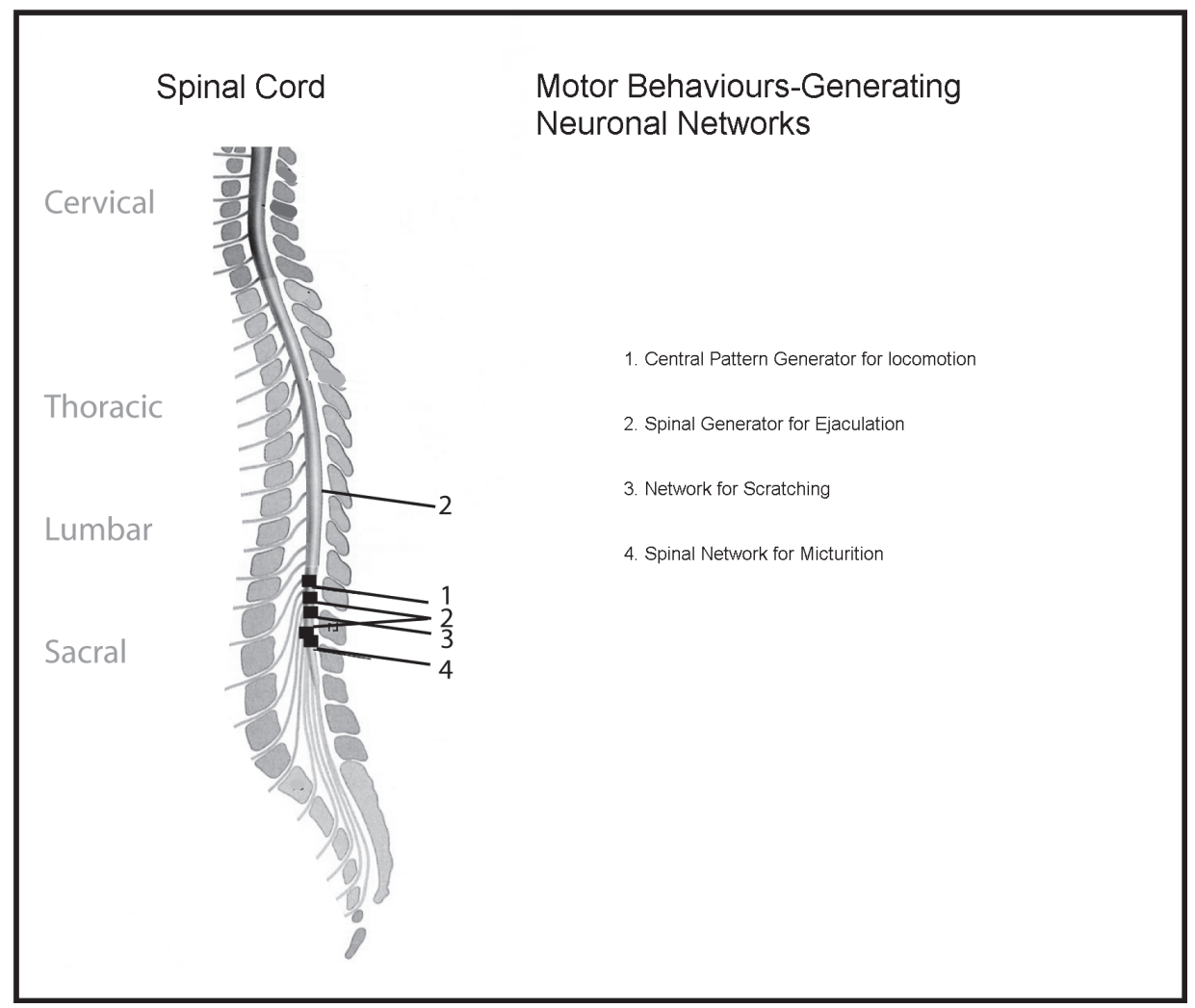

Fig. 1. Neuronal networks in the spinal cord that control, brain-independently, complex motor behaviours. Respiration (not shown here) is also largely controlled by non-cortical structures including the brainstem (e.g., Pre-Bötzinger complex).

Thus, the CNS controls either directly or indirectly the muscular systems. Although some types of muscles such as the cardiac and smooth muscles are considered controlled by the autonomic nervous system and hormones, the striated skeletal muscle system is directly controlled by the CNS. This is the main reason why after SCI, an immediate and irreversible 
loss of sensory and voluntary motor control is found. This said, increasing evidence suggests that functions controlled mainly by the spinal cord can nonetheless be elicited despite SCI using specific pharmacological or electrical approaches (see section 2.6).

In humans, the striated skeletal muscle system comprises approximately 650 muscles. It is formed by different fiber types and properties including slow-twitch fibers (type I) and relatively fast to very fast-twitch fibers (IIa, IIb and IIx)(Table 3). The main action of skeletal muscles in motor control is to allow movement execution. Almost all skeletal muscles either originate or insert on the skeleton. When a muscle moves a portion of the skeleton, that movement results into flexion, extension, adduction, abduction, etc. (Martini \& Nath, 2011). The human skeleton consists of both fused and individual bones supported by ligaments, tendons, muscles and cartilage. Among several functions, it primarily serves as a scaffold for movements controlled by the CNS and muscles as mentioned earlier. The biggest bone in the body is the femur which is also the main skeletal structure affected after chronic SCI, disuse or immobilization. Finally, energy and other metabolic processes involved in motor control and movements largely depend upon the integrity of the circulatory and hematologic systems - i.e., distribution of erythrocytes and oxygen to muscles.

\begin{tabular}{|l|l|}
\hline Type I & Slow twitch, high fatigue resistant, high oxidative, low glycolytic \\
Type IIa & $\begin{array}{l}\text { Moderately fast twitch, fairly high fatigue resistant, high oxidative, high } \\
\text { glycolytic }\end{array}$ \\
\hline Type IIx & $\begin{array}{l}\text { Fast twitch, intermediate fatigue resistant, intermediate oxidative, high } \\
\text { glycolytic }\end{array}$ \\
\hline Type IIb & Very fast twitch, low fatigue resistant, low oxidative, high glycolytic \\
\hline
\end{tabular}

Table 3. Muscle fiber types and main properties

All in all, the main components of the motor system described above are changed and altered specifically in patients with complete and motor-complete SCI as well as in patients suffering of chronic disuse and immobilization (burn patients, AIDS patients, some patients with cardiac or pulmonary problems)(Huang \& DeVivo, 1990; Bauman, 1999; Riegger et al., 2009; Rouleau et al., 2010,2011; Spungen, 2003; Lainscak et al., 2007).

\subsection{Spinal cord-transected murine model of complete paraplegia}

In brief, all experimental procedures were conducted in accordance with the Canadian Council on Animal Care guidelines. Mice were generally housed 4-5 animals per cage in a controlled-temperature environment $\left(22 \pm 3^{\circ} \mathrm{C}\right)$, maintained under a $12 \mathrm{~h}$ light:dark cycle with free access to water and food. Before surgery, pre-operative care was provided 30 minutes prior to anesthesia. It included subcutaneous injections of $1.0 \mathrm{ml}$ of lactate-Ringer's solution, $0.1 \mathrm{mg} / \mathrm{kg}$ of buprenorphine, and $5 \mathrm{mg} / \mathrm{kg}$ of Baytril, an antibiotic. Initially, complete anesthesia was conducted using $2.5 \%$ isoflurane in a cage of induction. Anesthetized animals were then shaved dorsally $(2-\mathrm{cm})$ from the mid-dorsal area to the neck. Then, each animal was maintained under complete anesthesia using a specially adapted facial mask delivering directly $2.5 \%$ isoflurane to the animal. The shaved area was cleaned with $70 \%(v / v)$ isopropyl alcohol and, then with $10 \%(v / v)$ povidone-iodine solution whereas eyes are protected from dryness using ocular lubricant. The first skin incision was made using fine scissors over $2 \mathrm{~cm}$ along the midline from the mid-dorsal area to the neck. Fat tissues (interscapularis fat) were cut and removed to expose the high-thoracic segments. 
The latissimus dorsi fascia was cut bilaterally to expose the vertebral column between the $4^{\text {th }}$ and $6^{\text {th }}$ thoracic vertebrae. Curved forceps were then used to tightly hold that area of the vertebral column that was cleaned from fascia and muscles to improve the grip. Forceps were also used to gently lift that part of the vertebral column which, once bent upward, eased the transection of the intervertebral ligaments between the $9^{\text {th }}$ and the $10^{\text {th }}$ vertebrae. This last part was critical to offer an open access for insertion of extra fine microscissors between the $9^{\text {th }}$ and $10^{\text {th }}$ thoracic vertebrae for the complete transection of the spinal cord. Then, the inner vertebral walls were explored and entirely, but delicately, scraped three or four times with fine scissors tips in order to sever any small fibres which had not been previously cut. It is important to scrape carefully to avoid severing the intervertebral ligaments located ventrally (i.e., if severed, it may lead to a dislocation of the vertebral column and corresponding bleeding). Throughout the transection procedures, bleeding although minor was controlled by applying pressure with cotton tips. The interscapularis fat was carefully replaced and the opened skin area was closed using 3 or 4 Michel suture clips. Michel suture clips are generally faster to install and are normally associated with less infection problems than typical suture threads. This overall surgical procedure was conducted under aseptic conditions using only perfectly cleaned materials and surgical tools - materials were previously autoclaved and tools were continuously sterilized throughout the procedure using a portable quartz beads-sterilizer).

Once the surgical procedures completed, anesthesia was interrupted and mice were placed in a large cage equipped with a heating pad placed underneath. It is critically important to use only minimal heating intensity $\left(35^{\circ} \mathrm{C}\right)$ to avoid rapid dehydration, heat shock and death during the recovery period. Generally, the animals recovered completely within $15 \mathrm{~min}$ although we normally left them on the heating pad overnight with free access to food and water. The recovery procedure was found to be critical to ensure a high percentage of survival post-surgery (typically around $95 \%$ if everything is performed as described). The next day, the animals were replaced in their initial cage with their initial cage mates in order to reduce potential aggressions and fights.

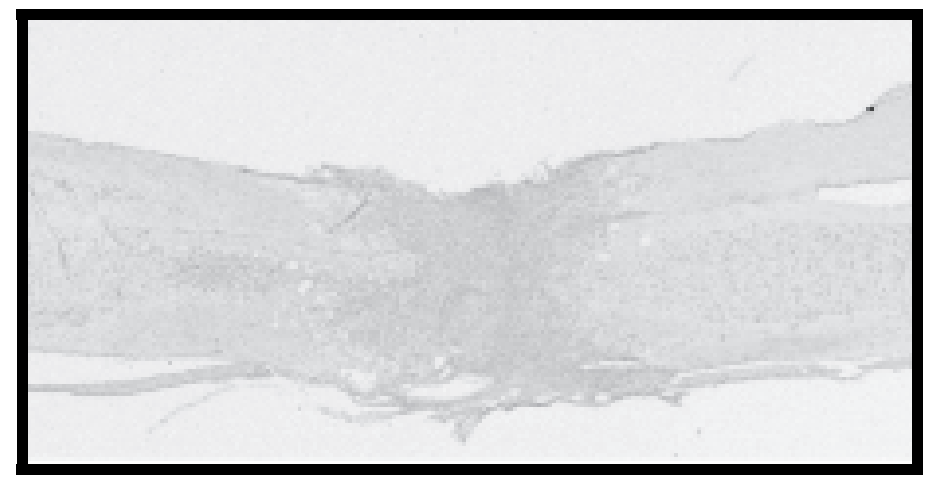

Fig. 2. Spinal cord histology. Luxol blue and Cresyl violet staining of a longitudinal section of the spinal cord from a non-laminectomized spinal cord-transected mouse one week postsurgery.

Postoperative care, provided a few hours after surgery as well as every day for the next 4 days, included injections of lactate-Ringer's solution $(2 \times 1 \mathrm{ml} /$ day, s.c. $)$, buprenorphine $(2 \times$ 
$0.1 \mathrm{mg} / \mathrm{kg} /$ day, s.c.), and Baytril $(5 \mathrm{mg} / \mathrm{kg} /$ day). Bladders were also manually emptied twice a day until a spontaneous return of some micturition reflexes. For voiding, the bladder was gently squeezed between the thumb (side of the bladder) and two fingers (e.g., the index and one other finger placed the other side of the bladder). This maneuver requires time and experience. In male mice, it was specifically challenging since, in addition, penises have to be maintained against a paper towel throughout the maneuver to improve successful voiding (i.e., it appeared to contribute, perhaps via capillary action, to urine expulsion outside the urinary tract). The belly and sexual organ were cleaned daily using paper towels and chlorhexidine gluconate solution $(0.05 \% v / v)$ to prevent urinary infection. Normally, with these procedures, mice that survived the firsts 24 hours, remained relatively healthy for a long period of time (i.e., several months). Finally, Michel suture clips were removed after 10 or 14 days post-surgery. Cages were cleaned regularly (ideally, cages needed to be changed every 3 or 4 days) and mice were cleaned, as described above, on a daily basis to prevent urinary tract infection. All in all, once anesthetized, this surgical procedure took no longer than five minutes whereas another 5-10 minutes was typically required for animals to recover from anesthesia.

This approach led to complete paraplegia (Figs. 2 \& 3) - an immediate and irreversible loss of sensory and voluntary motor control below injury level (low-thoracic level). Although, it is possible to maintain these animals relatively healthy for severaonmonths post-spinal transection, a number of neuronal, muscular, skeletal, vascular, and hematologic changes were rapidly displayed. A detailed characterization of these changes is presented in the following subsections.

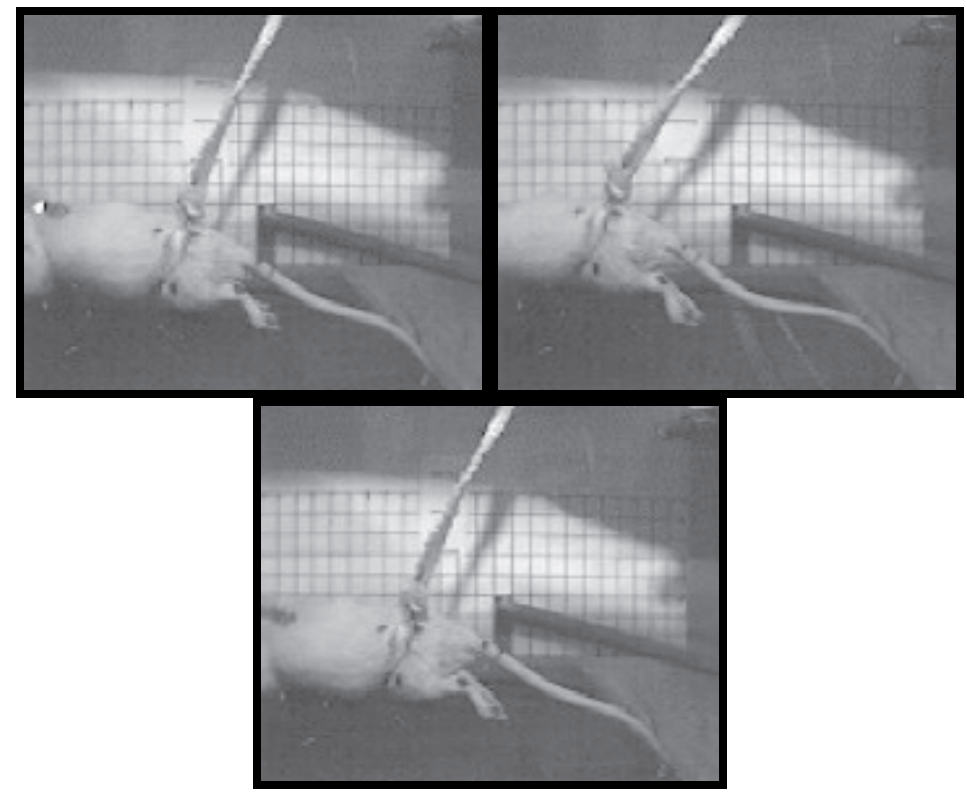

Fig. 3. Video images of a paraplegic mouse placed on a treadmill. A complete loss of hindlimb movement is encountered immediately following the spinal cord transection. 


\subsection{Disuse-related bone loss, biomechanical property changes and factures}

Nearly all SCI individuals experience a drastic loss of bone mineral content (up to $30 \%$ at the femoral level) leading to a marked increase of fracture incidence within one year after injury (Ragnarsson \& Sell, 1981; Garland et al., 1992; Wilmet et al., 1995; Lazo et al., 2001; Sabo et al., 2001). Although, the basic mechanisms underlying osteoporosis in post-menopausal women have been extensively studied, those involved in chronic immobilization and disuse have received considerably less attention. In animal models of disuse, traditionally in rats, hindlimb immobilization has been found to induce a drastic and sudden loss of femoral bone tissue suggesting that different mechanisms may be involved in disuse vs. estrogendeficiency/aging-related osteoporosis (Bagi \& Miller, 1994). For instance, a 10-30\% decrease of cancellous bone has been reported within only a few weeks in the ipsilateral femur of rats that had their hindlimbs immobilized with a cast or an elastic bandage (Ito et al., 1994; Ma et al., 1995; Mosekilde et al., 2000). Comparable changes have been found in other models of disuse such as in tail-suspended rats (Wronski et al., 1989). Some of these disuse-related changes are believed to be mediated by both an increase of osteoclastic bone resorption and a decrease of osteoblastic bone formation (Rantakokko et al., 1999). On the other hand, growing evidence suggests that several factors other than mechanical unloading per se can influence the combination of cellular and molecular mechanisms underlying disuse-related bone loss. For instance, in the case of disuse induced by a lesion of the sciatic nerve, the loss of bone tissue in rats is caused partly by a disruption of the neurogenic innervation of the bone marrow (Zeng et al., 1996). Moreover, differential tissue- and biomarker-specific changes have been reported in the tail-suspension vs. sciatic nerve lesion models (Hanson et al., 2005). In the case of microgravity, bone tissue changes have been attributed mainly to a marked decrease of osteblast formation in young adult rats (Matsumoto et al., 1998). Taken together, those data suggest that the combination of various factors specific to each model and condition of disuse may dictate, to some extent, the different sets of molecular mechanisms involved in demineralization and bone loss.

Here, we characterized some of the main structural and functional adaptive changes occurring specifically within a few weeks in adult spinal cord transected mice. In brief, within a few weeks post-transection, paraplegic mice were weighed, sacrificed and the femoral bones dissected and cleaned of soft tissue. The femurs were wrapped in salinesoaked gauze and frozen at -20 degrees $C$ in sealed vials until testing. For histomorphometry, the left femoral bones were fixed with paraformaldehyde, decalcified, paraffin embedded and stained with acid fuchine using the Masson's trichrome procedures. Histomorphometric analyses were performed with a NOVA Prime, Biioquant's image analysis system (R\&M Biometric, Nashville, TN) for primary bone morphometric parameters. Three bone slices at the metaphyseal level were analyzed. For densitometry, measurements were made with the rigth femoral bones of sham and paraplegic mice. Bone mineral content (BMC, g) from the femora of each animal was assessed using dual-energy Xray absoptiometry (DEXA, model Piximus II, Lunar Corporation, Madison WI, for details, see Kolta S, De Vernejoul M.C. et al. 2003). Bone mineral density (BMD, g/ $\mathrm{cm}^{2}$ ) was calculated as BMC divided by projected bone area. Each femur was scanned separately for whole bone analysis. For biomechanical assessment, on the day of testing, the femur was slowly (4 hours) tawed at room temperature. They were placed horizontally on the threepoint bending device (MTS, Eden Prairie, MN). The mechanical resistance to failure was tested using a servo-controlled electromechanical system (Intron, Instron, Canton, MA). The crosshead speed for all tests was $10 \mathrm{~mm} / \mathrm{sec}$ until the femur fractured. Displacement and 
load values were acquired at $100 \mathrm{~Hz}$, recorded and stored on PC. Off-line data analyses were performed to calculate maximal strength $(\mathrm{N})$, stiffness (slope of the linear part of the curve to failure, $\mathrm{N} / \mathrm{cm}$ ), and elasticity deformation $(\mathrm{N})$. Bones were kept wet throughout testing and used for histomorphometrical testing (proximal end).

All histomorphometric measurements and analyses were made from the metaphyseal area of the left femora. The cancellous bone volume was found to decrease by $25.2 \%$ in paraplegic mice (within 1 month post-transection) compared with control (non-paraplegic). The average trabecular bone thickness was found to decrease by $10.65 \%$. The thickness was initially of 25.55 micron in the control groups and of only 22.83 micron in the paraplegic group. The number of trabecular bone areas decreased rapidly also after injury. In the control group, the average trabecular number was $3.38 \mathrm{nbr} / \mathrm{mm} 2$ whereas in the paraplegic group, it decreased to only $2.89 \mathrm{nbr} / \mathrm{mm} 2$ representing a $14.50 \%$ decrease. On the other hand, the trabecular separation, defined as the space between trabecular bone areas, increased after injury. In fact, on average, the trabecular separation increased by $24.03 \%$ within 1 month post-SCI (Picard et al., 2008).

The bone mineral density (BMD) of the left femora measured by dual-energy X-ray absorptiometry (DEXA) significantly changed after injury. The BMD was just below 0.09 $\mathrm{g} / \mathrm{cm} 2$ in control and of 0.0731 in paraplegic mice. Bone mineral content (BMC) also proportionally decreased after injury (see sections 2.6 and 2.7 for further details).

The maximum force in $\mathrm{N}$ required for the crosshead to fracture the right femora at the middiaphyseal level was decreased by $13 \%$ on average within a few weeks post-transection (Fig.4D). The stiffness in $\mathrm{N} / \mathrm{mm}$ was also reduced after injury with average values of 57.23 and 51.08 in control and paraplegic groups, respectively, representing a $10.8 \%$ decrease (Fig.4B). The elastic force decreased also by approximately $15 \%$ in early spinal transected mice compared with control (Fig.4C).

\subsection{Muscular atrophy, muscle fiber-type conversion, and strength loss}

It is well-documented in various rat models that the contractile properties of slow twitch muscles change into more fast-like muscles after chronic spinalization (Roy et al., 1991; Talmadge, 2000). Hindlimb extensor muscles such as soleus (SOL) typically exhibit extended atrophy (e.g., up to 50\%) and type I to type II muscle fiber conversion following spinalization in rats (Krikorian et al., 1982; Lieber et al., 1986 a,b; Midrio et al., 1988; Talmadge et al., 1995). Contraction and relaxation times as well as maximal tetanic force (Po) and maximal twitch force $(\mathrm{Pt})$ have also been found to be importantly decreased in rat SOL several months after spinalization (Davey et al., 1981; Talmadge et al., 2002).

Evidence from other models of inactivity and immobilization suggests that some of these changes, in fact, are induced very early after inactivity and reduced muscular activity and loading. For example, a 10\% loss of body weight (Pierotti et al., 1990) accompanied by a $40-$ $50 \%$ decrease of SOL mass, TPT and 1/2 RT (Frenette et al., 2002) and a rapid reduction in slow myofibril proteins (Thomason et al., 1987) have been reported after 1-2 weeks of hindlimb suspension in rats. Comparable results have been found within less than 2 weeks in rats after spinal cord isolation (i.e., de-afferented and spinalized, Grossman et al., 1998) or in microgravity (Fitts et al., 2001). In addition, a $40 \%$ reduction of SOL cross sectional area has been found only 10 days post-spinal cord transection in rats (Dupont-Versteegden et al., 1999). The possibility that other early changes may occur after spinal cord transection is largely unexplored. 


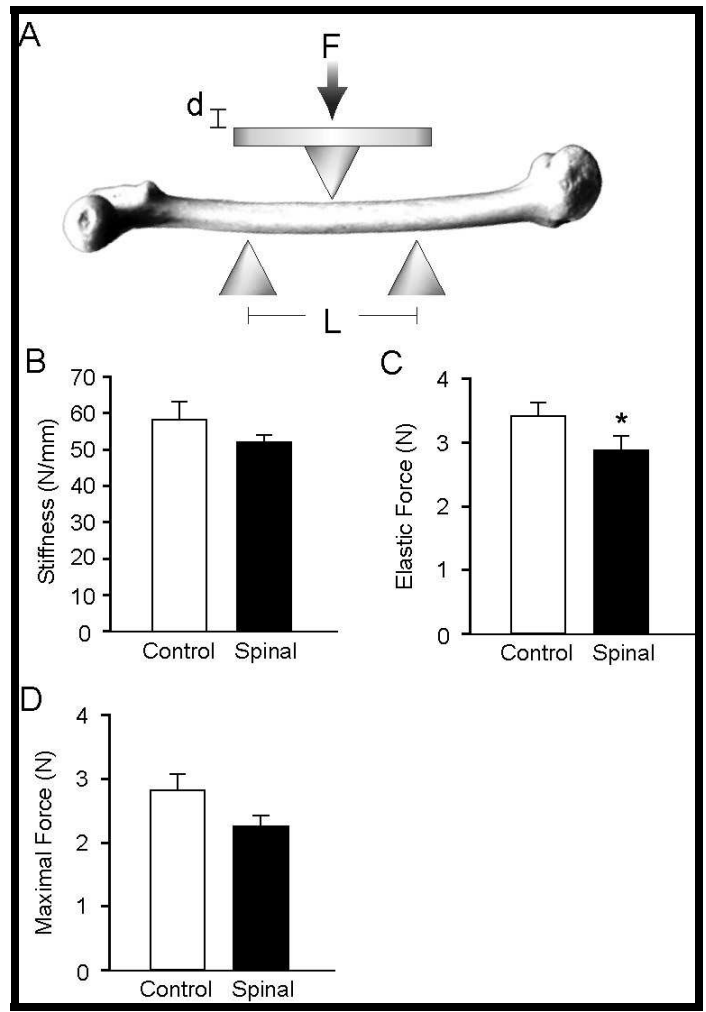

Fig. 4. Bone mechanical properties. Two-point bending test (A) revealed decreased femoral stiffness (B), elasticity (C) and maximal force (D) in untrained spinal transected mice (spinal, black) versus control (intact animals, white)(unpublished data).

Here, we characterized some of the earliest adaptations in gross anatomy and muscle properties at only 7 days following spinal cord transection in adult mice (Landry et al., 2004). In brief, whole body weight was measured daily during the first week postspinalization. After dissection of SOL for functional tests in vitro (see section below), animals were sacrificed with pentobarbital overdose. Forelimbs and hindlimbs were surgically removed just below the shoulder and the hip joints respectively. Paws as well as all parts of the pectoral and back muscles attached to the forelimbs were removed. Tests included weight measurement of the left forelimb and hindlimb as well as of the right SOL. To further assess muscle atrophy, limbs were weighed in air and in water to measure volume changes. Volume was calculated as follows with a volumic mass of 0.998 for water at room temperature $\left(22^{\circ} \mathrm{C}\right)$ :

$$
\text { Volume }=(\text { weight in air }- \text { weight in water }) \times(\text { volumic mass of water })
$$

For measurement of contractile properties, we anesthetized animals with pentobarbital sodium $(50 \mathrm{mg} / \mathrm{kg})$. The right $\mathrm{SOL}$ was carefully dissected and incubated in fully oxygenated Krebs-Ringer bicarbonate buffer solution maintained at $25^{\circ} \mathrm{C}$ and supplemented 
with glucose $(2 \mathrm{mg} / \mathrm{ml})$. In vitro measurement of muscle contractile properties was performed as described elsewhere (Côté et al., 1997). In brief, one tendon was attached to a rigid support at the bottom of the bath, and the other end was connected to an isometric force transducer (Grass FT-03) through a stainless steel hook. An initial resting period of 15 min was allowed before testing. Muscles were carefully stretched to their optimal length, defined as the length at which maximal isometric twitch tension is produced. One single twitch contraction was elicited and the following measurements were obtained: maximum twitch tension (Pt), time-to-peak tension (TPT), and one-half relaxation time (1/2 RT). After measurement of twitch parameters, muscles were stimulated for $1 \mathrm{~s}$ at frequencies of 10, 20, $35,50,80$, and $100 \mathrm{~Hz}$ to determine maximal tetanic tension $\left(\mathrm{Po}, \mathrm{N} / \mathrm{cm}^{2}\right)$. The value used for muscle density was $1.062 \mathrm{~g} / \mathrm{cm}$ (Koh \& Brooks, 2001) and the ratio of fiber length to muscle length used was 0.71 (Brooks \& Faulkner, 1988).

We reported that paraplegic mice at 7 days post-surgery encountered a drastic loss in body weight (Landry et al., 2004). On average, a $24 \%$ decrease in weight was found at 7 days post-spinalization. A similar loss was found in another group of paraplegic mice that received instead daily injection of lactate-Ringer's solution $(2 \mathrm{ml} /$ day, s.c.) during the first week post-spinalization suggesting that dehydration did not contribute to weight loss.

The specific weight of individual body parts was also examined in paraplegic mice. In intact mice, the average weight of forelimbs and hindlimbs was 436 and $1239 \mathrm{mg}$ respectively. At 7 days post-spinalization, hindlimb weight decreased by $28 \%$ compared to intact mice. Interestingly, a $21 \%$ reduction in the forelimbs of paraplegic mice was also observed during the same period of time. Relative to body weight, the loss observed in hindlimbs was greater than the one in forelimbs. Similar reductions in volume were found respectively in hindlimbs and forelimbs.

Regarding properties, for soleus mass displayed significantly lower values (-32\%) in untrained paraplegic mice at 7 days post-spinalization compared with intact animals. A 33\% decrease of Po was measured at 7 days post-spinalization. The absolute tension generated at different frequencies of stimulation showed mainly that SOL force was reduced in paraplegic mice compared to control at stimulation frequencies above $35 \mathrm{~Hz}$. On the other hand, maximal tension was reached at lower stimulation frequencies for paraplegics compared to control.

Our data showed also in soleus a change toward faster-type properties in the first few days post-immobilization (transection).The surprising initial and rapid conversion to slower contractile properties at 7 days post-spinalization is further supported by changes found in contraction and relaxation times (TPT and 1/2 RT respectively). TPT became slower (i.e., increased time of contraction) by $21 \%$ at 7 days compared to control. Similar changes were observed with $1 / 2$ RT which became slower (i.e., increased time of relaxation) by $48 \%$ at 7 days post-spinalisation.

As mentioned above, it is well-known that there is an important shift in fiber phenotype distribution a few weeks post-SCI even more so in soleus. Generally, slow fibers tend to change for a faster phenotype after 2 weeks post-spinal cord transection. After spinal cord transection, $50-55 \%$ of the slow type fibers showed important fiber type conversion, shifting to a hybrid isoform (faster phenotype) whereas fiber type conversion was not observed in another hindlimb muscle, EDL, often classified as a purely fast-twitch muscle (Table 4). 


\begin{tabular}{|l|l|l|}
\hline Fiber type \% & Non-TX & TX untrained \\
\hline EDL type II & $98.7 \pm 0.3$ & $98.7 \pm 0.6$ \\
\hline EDL hybrid & $1.3 \pm 0.3$ & $1.3 \pm 0.6$ \\
\hline SOL type I & $54.6 \pm 2.6$ & $2.9 \pm 1.5$ \\
\hline SOL type II & $45.4 \pm 2.6$ & $46.5 \pm 2.5$ \\
\hline SOL hybrid & $0 \pm 0$ & $50.7 \pm 3.3$ \\
\hline
\end{tabular}

Table 4. Fiber type conversion in normal (non-TX) and untrained paraplegic (TX untrained)(unpublished data).

\subsection{Circulatory and hematologic changes associated with increased risks of blood cloth formation and deep vein thrombosis}

Among the cardiovascular and pulmonary problems associated with SCI, deep venous thrombosis (DVT) is one of the most serious complications in patients that survive to the accident. Indeed, DVT constitutes the third most common cause of death in SCI patients (Waring \& Karunas, 1991; DeVivo, 1999) and, despite prophylaxic methods (e.g. anticoagulant administration), a significant proportion of SCI patients will develop a pulmonary embolism caused by DVT (Deep et al., 2001).

Complete paraplegic and tetraplegic individuals are particularly vulnerable given that spasticity, typically found in incomplete SCI patients, may decrease the risks of DVT formation (Green et al., 2003). Generally, DVT formation is attributed to a combination of factors including also venous stasis, venous injury, and hypercoagulability. In turn, these factors facilitate platelet, LDL-cholesterol, and leukocyte adhesion, procoagulant system activation, and hence, thrombin generation. Although, few animal models of DVT and/or pulmonary embolism exist (Frisbie, 2005), none have been developed to study these complications after SCI which may explain why the specific mechanisms of DVT formation in paralytics remain poorly understood.

Here, we characterized, in spinal cord transected (Tx) mice, some of the physiological changes occurring after SCI that could possibly contribute to DVT formation (Rouleau \& Guertin, 2007; Rouleau et al., 2007). Specifically, we characterized also alterations of deep vein diameter in the hindlimbs of $\mathrm{Tx}$ mice because venous distensibility and capacity changes may participate to DVT formation (Miranda \& Hassouna, 2000). We took advantage of this experimental model to measure with great precision $(\mu \mathrm{m})$, using in vivo fluorescence confocal microscopy, changes in diameter of the femoral and saphenous veins. All tests were performed weekly during one month post-Tx since risks of DVT in patients have been reported to increase by several folds specifically during the first few weeks after SCI (DeVivo et al., 1999).

In brief, we put the tail on a heated cushion to dilate the tail vein $10 \mathrm{~min}$ before injection. Then $200 \mu \mathrm{l}$ of $5 \mathrm{mg} / \mathrm{ml}$ fluorescein isothiocyanate-dextran (FD-40) (Sigma, St-Louis, MO) dilute in injectable endotoxin-free dPBS (Sigma), was injected intravenously into the tail vein. Animals were killed by $\mathrm{CO}_{2}$ asphyxiation around $10 \mathrm{~min}$ after injection. The skin was cut to access to the femoral and saphenous veins. Microscope observation and measurement were performed with an Olympus BX61WI confocal system and analysed with Fluoview 300 (Carsen group, Markhan, Canada).

For hematologic data, peripheral blood was collected at various times post-transection by cardiac puncture. Each blood sample was analyzed for platelet quantification with a CELLDYN $370{ }^{\circledR}$ automatic blood cell analyzer (CD3700)(Abbott Laboratories, North Chicago, IL). 
We found by measuring deep vein diameter using in vivo fluorescent confocal microscopy techniques that the femoral and saphenous veins drastically increased in size after SCI compared with intact mice. This is illustrated in Fig. 5 showing typical examples from a control (left panel) and from a paraplegic mouse at 3 week post-TX (right panel). We can clearly distinguish that the femoral vein drastically increased in size post-transection compared with control. In fact, average values calculated for the femoral vein revealed, for control animals, an average diameter of $319 \mu \mathrm{m}$ augmented to $458 \mu \mathrm{m}$ at 3 weeks postsurgery (Fig. 5). Comparable increases of saphenous vein diameter were found after spinal transection (338 $\mu \mathrm{m}$ in control vs 433 in paraplegics)

The hematologic data revealed mild anemia that occurs as early as at 7 days posttransection. Specifically, average counts of erythrocytes $\left(10.11 \times 10^{12} / \mathrm{L}\right.$ in control mice) decreased to values ranging from 9.91 to $9.54 \times 10^{12} / \mathrm{L}$ in paraplegic mice. Hemoglobin concentrations were decreased from $164.9 \pm 2.8 \mathrm{~g} / \mathrm{L}$ in controls to $153.3 \mathrm{~g} / \mathrm{L}$ in paraplegic mice. Decreased hematocrit levels were also found in paraplegic mice (range from $0.46 \pm$ 0.01 to $0.44 \pm 0.01 \mathrm{~L} / \mathrm{L})$ compared with controls $(0.48 \pm 0.01 \mathrm{~L} / \mathrm{L}$, Fig. $1 C)$. In turn, platelet counts remained unchanged after spinal transection with levels of $16.76 \pm 0.80 \times 10^{11} / \mathrm{L}$ in controls and $17.73 \pm 0.75$ in paraplegic mice (Rouleau et al., 2007).

\subsection{Complex spinal cord network that controls locomotor rhythm generation}

The Central Pattern Generator (CPG) for locomotion is a network of neurons located in the lumbar area of the spinal cord that is capable of producing the basic commands for stepping even when isolated from supraspinal and sensory inputs (Grillner \& Zangger, 1979, see also Guertin, 2010). Early evidence of a CPG emerged a century ago from the pioneer work of Sherrington (1910) and Brown (1914). In the 70s, low-thoracic spinalized rabbits and cats were used to show that an endogenous release of 5-HT induced by 5-HTP can generate fictive locomotor-like rhythms in the spinal cord (recorded with electroneurograms) of acute spinal cord-transected animals (Viala \& Buser, 1971) or increase extensor muscle activity in regularly treadmill-trained and sensory-stimulated spinal animals (Barbeau \& Rossignol, 1990, 1991). A clear demonstration of its existence was provided in 1979 by Grillner who could induce, with L-DOPA, locomotor-like neural activity in the motor nerves of completely de-afferented, curarized, and spinal cordtransected cats (Grillner \& Zangger, 1979). In rats, the CPG was found, with activitydependent labeling (e.g., c-fos), to be located mainly in rostral segments of the lumbar spinal cord (Cina \& Hochman, 2000). Comparable results were found in mice where CPG activity was found to originate from lumbar segments with critical elements in L1-L2 (Nishimaru et al., 2000).

In the 80 s and 90 s, in vitro isolated spinal cord preparations were extensively used to study the pharmacological control of CPG neurons at the system and cellular levels. Initially discovered in lampreys, bath application of N-methyl-D-asparate (NMDA) was found to induce rhythmic activity (recorded from ventral roots) that shared locomotor characteristics - called 'fictive locomotion'. This provided evidence that even a perfectly isolated CPG can be activated with drugs. Then, neonatal rat and mouse spinal cord isolated preparations were developed and used also to study in vitro drug-induced CPG-mediated locomotor-like neurographic activity. These studies have essentially revealed that bath-applied combinations of drugs such as NMDA, 5-HT and DA can best induce robust fictive locomotor-like rhythms in the mammalian isolated spinal cord (Cazalets et al., 1992; 
Kjaerulff \& Kiehn, 1994). Although, these studies have revealed that several families of drugs need to be combined for enhanced CPG activation, most of the compounds used in vitro were synthetic neurotransmitters (e.g. 5-HT and DA) which, unfortunately, do not constitute good candidates for drug treatments because of poor selectivity (e.g. activation of all receptor subtypes) and incapacity to cross the BBB.

In humans, evidence of a CPG was provided after showing that 'automatic' (involuntary) stepping-like movements could be triggered spontaneously under certain conditions or by epidural stimulation at the L2 level in SCI patients confined to a bed (Dimitrijevic et al., 1998). Although a completely isolated CPG can produce locomotor rhythms, sensory inputs (i.e. muscle proprioception, vision, etc.) were found to provide useful feedback signals to the CPG that can re-enforce muscle contraction and adapt stepping to external disturbances (Rossignol \& Dubuc, 1994). However, none of these studies have identified a full CPG-activating drug that can, upon systemic administration, potently elicit acutely powerful weight-bearing stepping in complete SCI animals with no other stimulation/assistance (e.g., non-therapetically relevant tail pinching or other sensory stimulation).

Changes post-spinal cord transection were also found in sublesionally-located neurons (below injury level). Since most of these changes were found in neurons located in upper lumbar segments of the spinal cord, they were postulated to correspond with changes in CPG neuron candidates. Immediate early genes (IEGs) constitute a large family of genes well-known as early regulators of cell growth, differentiation signals, learning and memory. We reported in low-thoracic spinal cord-transected mice, that IEGs such as $c$-fos and nor-1 expression respectively increased and decreased within a few days in the segments L1-L2, specifically in the dorsal horn and intermediate zone areas (Landry et al., 2006). Changes in the lumbar spinal cord of rostrally-transected animals were of special interest since some of these segments (e.g., L1-L2 in mice) were shown to contain critical central pattern generator (CPG) elements as mentioned earlier. Given that IEGs are better known for their role in CNS development and plasticity, spontaneous changes of IEG expression (i.e., specifically c-fos and nor-1) in L1-L2 segments may be considered as among the first sublesional cellular events associated with altered cellular functions and properties post-SCI. This said, some of these changes may be associated also with other phenomena than plasticity or reorganization of spinal motor and locomotor networks. For instance, $c$-fos and nor- 1 were used as markers in experimental models of pain and transient global ischemia suggesting a role in several functions (see Landry et al., 2006a).

Other key elements including transmembranal receptors may be considered good candidates for plasticity and reorganization of motor and locomotor networks located sublesionally following a spinal cord-transection (and probably to some extent also after partial injuries). For instance, we found using in situ hybridization increased 5- $\mathrm{HT}_{1 \mathrm{~A}} \mathrm{mRNA}$ levels in L1-L2 segments in 5-HT7-deficient mice compared with wild-types (Landry et al., 2006b). This was interpreted as evidence suggesting that even greater changes may occur post-trauma in absence of functionally closely-related genes. Results in mice revealed also increased 5- $\mathrm{HT}_{2 \mathrm{~A}}$ mRNA levels in lumbar segments (laminae VII, VIII, and IX) several days after a low-thoracic transection (Ung et al., 2009).

All in all, it is unclear how these changes of neuronal properties and gene expression below lesion level may affect functional recovery and, specifically, the development of approach 
designed to reactivate behaviours-generating neuronal networks (e.g., CPGs for locomotion, micturition, ejaculation, etc.). Nonetheless, it has been postulated by others that such changes may contribute to increase sublesional network excitability and, thus, may facilitate training-induced learning and rehabilitation.

\subsection{Advanced locomotor training induced pharmacologically as a treatment against motor system changes in $\mathrm{SCl}$}

Given that no cure exists yet to repair the spinal cord, an interesting avenue to prevent or reduce some of the motor system changes described in previous sections of this chapter may be to pharmacologically induce episodes of locomotion. To achieve this, an alternative strategy could be to develop a CPG-activating drug treatment that could temporarily re-activate this sublesional network in tetraplegic and most paraplegic subjects.

Experiments mainly conducted in my laboratory since 2004 have led to a better understanding of pharmacological CPG activation in vivo. In brief, we found in completely low-thoracic spinal cord-transected mice that a few subtypes of blood brain barrier (BBB) permeable molecules can elicit partial CPG-activating effects (i.e., locomotor-like movements or LMs that resemble crawling - successive flexions and extensions coordinated in both hindlimbs without weight bearing)(Guertin, 2004a; Landry \& Guertin, 2004; Landry et al., 2006; Lapointe et al., 2009). We subsequently found that drug combinations with some of these compounds including dopaminergic and serotonergic compounds (e.g., DA precursors such as L-DOPA combined with a decarboxylase inhibitor such as carbidopa, and a 5-HT1A receptor agonist such as 8-OHDPAT or buspirone, etc.), could elicit significantly greater CPG-activating effects including large amplitude LMs with some equilibrium, plantar foot placement and weight bearing capabilities (i.e., real stepping rather than crawling, Guertin 2004b; Lapointe \& Guertin 2008; Guertin et al., 2010, Guertin et al., 2011)(Fig.6). As mentioned earlier, this idea that drug combinations can produce apparently full CPG-activating effects was also supported by comparable findings in in vitro isolated spinal cord preparations (better and more stable fictive locomotor neuronal activities in isolated spinal cords, e.g., Cazalets et al., 1992; Kjaerulff \& Kiehn, 1994; Kiehn \& Kjaerulff, 1996; Jiang et al., 1999; Whelan et al., 2000).

This identification of a potent CPG-activating tritherapy (Guertin et al., 2010) recently received support from a special NIH program (Rapid Access to Interventional Development program) to conduct some of the preclinical studies (toxicity and safety pharmacology in rats). It has been determined that a tri-therapy composed of L-DOPA, carbidopa and buspirone is safe and ideally suited for further development at the clinical level (i.e., each drug is already FDA approved for diseases other than SCI and no abnormal pharmacology or toxicology data was found) as a first-in-class CPG activating drug treatment candidate. However, although efficacy in early chronic SCI mice has recently been demonstrated (Guertin et al., 2010; Guertin et al. 2011), it remains unclear how repeated administration over several weeks would affect disuse-related motor system changes.

As mentioned earlier, chronic SCI patients (especially motor-complete also called ASIA-A or ASIA-B patients) experience often life-threatening health problems also referred to as 
'secondary complications' including motor system changes reported here also in this paraplegic mouse model. Using combination therapy, we obtained preliminary data suggesting that repeatedly-treated paraplegic mice can partially prevent some pathophysiological motor system changes found after SCI (Guertin et al., 2011).

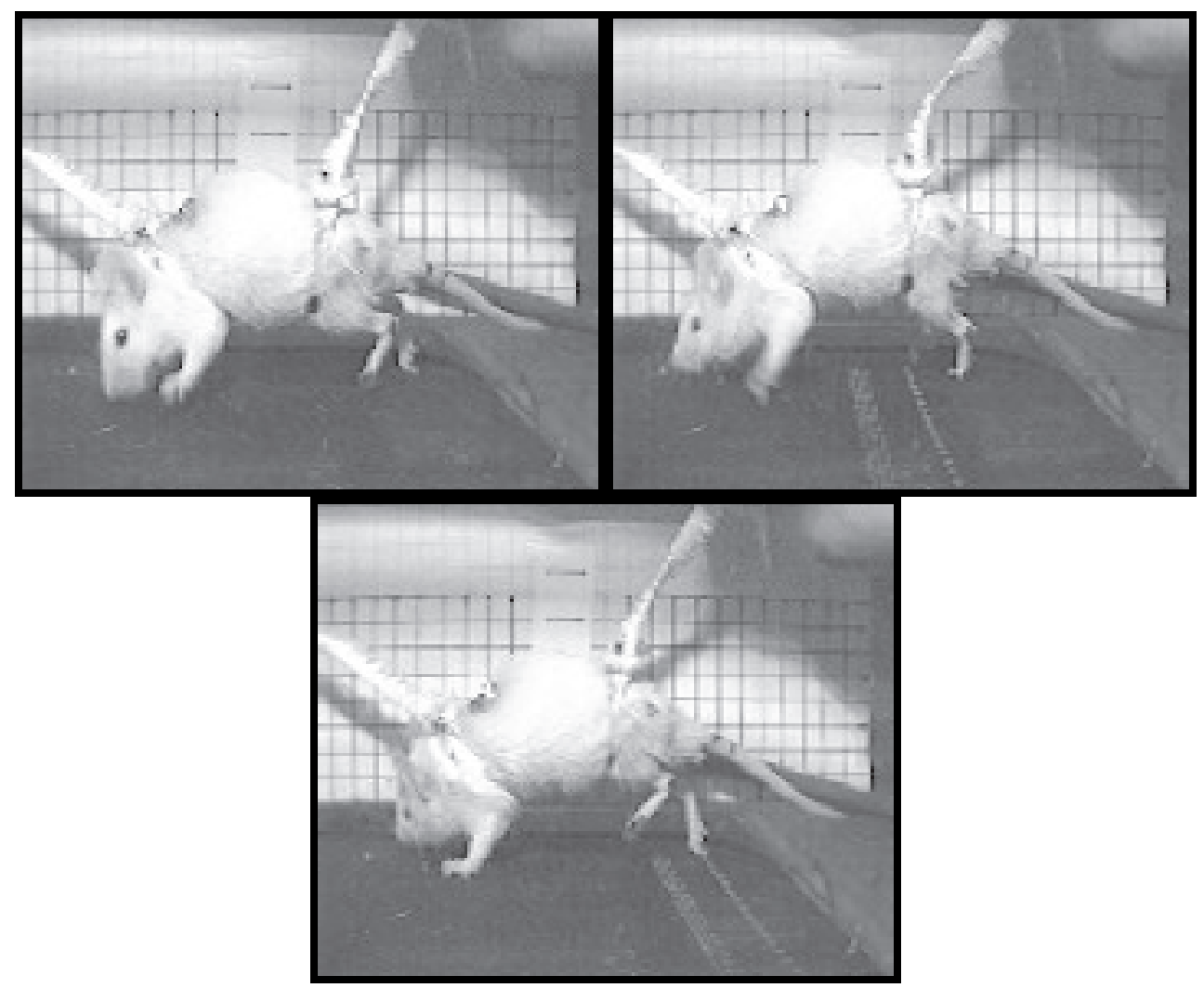

Fig. 5. Video images of a paraplegic mouse placed on a treadmill 15 minutes following administration of a CPG-activation tritherapy. Involuntary movements were generated for approximately 30 to $45 \mathrm{~min}$. Then a complete return to complete paraplegia occurred.

Subcutaneous administration (several times per week) of a first-generation combination treatment was found, upon each injection (within $15 \mathrm{~min}$ ), to repeatedly induce temporarily (during approx. 30-45 min) episodes of weight bearing stepping in non-assisted paraplegic mice at least during one month.

Regarding body weight values, combination therapy-treated paraplegic animals progressively displayed a moderate increase in weight suggesting that repeated administration of this combination therapy was well-tolerated (i.e., a loss of weight would have suggested toxic effects and additional health problems). No significant difference was found in bone mineral density (BMD) values in femoral bones of tritherapy-treated vs. placebo-treated paraplegic mice. Post-mortem examination of muscle size (whole surface area and fiber cross-sectional area or CSA) measured from cryostat transverse 
sections prepared from two hindlimb muscles, soleus (SOL) and extensor digitorum longus (EDL), was performed to assess the effect of combination therapy-induced training on muscular atrophy normally found after SCI. We found values corresponding with larger muscles and muscle fibers in the combination therapy-treated compared with the placebotreated paraplegic animals. Sol values increased by $24 \%$ in combination therapy-treated paraplegic mice $\left(0.61 \pm 0.05 \mathrm{~mm}^{2}\right)$ compared with placebo-treated ones $\left(0.49 \pm 0.03 \mathrm{~mm}^{2}\right.$, fig. 3A). Comparable results were found in EDL (combination therapy-treated $0.91 \pm 0.03$ $\mathrm{mm}^{2}$ vs. placebo-treated $0.77 \pm 0.06 \mathrm{~mm}^{2}$ )(not shown). At the cellular level, comparisons between combination therapy-treated and placebo-treated animals revealed that type I fiber CSA values non-significantly changed whereas type II fiber and intermediate fiber (type I + II labeled) CSA values significantly increased subsequently both by $8 \%$ (Fig. 3C, 3D). An analysis of muscle fiber-type ratios (i.e., proportion among all fibers of type I, type II or type I + II fibers) indicated that no significant changes were found between groups. Subpopulations of red blood cell (RBC) constituents were assessed and compared between groups. Levels of RBC, platelet, hemoglobin and hematocrit were significantly increased by $11 \%, 19 \%, 10 \%$ and $10 \%$, respectively, in combination therapy-treated vs. placebo-treated paraplegic animals.

All in all, these results revealed that pharmacological activation of the CPG four times per week during 1 month can prevent anemia and prevent partially muscle atrophy. Circulatory systems were not further examined in this study. On the other hand, this study showed that bone loss typically occurring post-transection in this animals can not be prevented in these conditions. Altogether, it is suggested that training conditions or treatments may have to be optimized for further physiological effects on all parts of the motor system.

Along this idea, we recently conducted a study where paraplegic animals received an anabolic agent, namely clenbuterol, in addition to tritherapy-induced locomotor training. We found that tritherapy-treated paraplegic mice with or without clenbuterol treatment displayed significant locomotor function recovery during 2 months upon each administration of the CPG-activating therapy (Fig.7). To further characterize movements induced by the tritherapy-training, angular excursion at the hip, knee and ankle, as well as movement amplitude values were analysed. Typical examples of hindlimb kinematics are shown in figure 7. Hip, knee and ankle angular displacement showed similar patterns in intact, tritherapy-trained alone and tritherapy-trained + clenbuterol paraplegic animals. Untrained paraplegic animals displayed a consistent lack of angular excursion at the hip level although some displacements were found at the knee and ankle levels (hip: $85^{\circ}$, knee: 30-47 , ankle: $28-125^{\circ}$ ). Hindlimb movement amplitude values measured by calculating toe displacement in $X$ and $Y$ axis (step "length" and "height") revealed that intact mice had greater step length values than both tritherapy-trained paraplegic groups. On the other hand, both groups of tritherapy-trained paraplegic animals showed similar step length values which were significantly greater than those in untrained paraplegic mice. The coefficient of variation $(\mathrm{CV})$ was higher in untrained mice. Intact, tritherapy-trained and tritherapy-trained + clenbuterol paraplegic mice showed similar step height values. However, differences were found in the variability of the step height, as shown by $\mathrm{CV}$, where intact animals displayed less variability than the other groups of tritherapy-trained animals. No $\mathrm{Y}$ axis movement amplitude was observed in paraplegic untrained mice since no weight-bearing movement are normally expressed spontaneously. Overall, a significant increase in performances over time was observed in tritherapy-trained groups of paraplegic mice movement kinematic values were comparable with those from intact animals. 


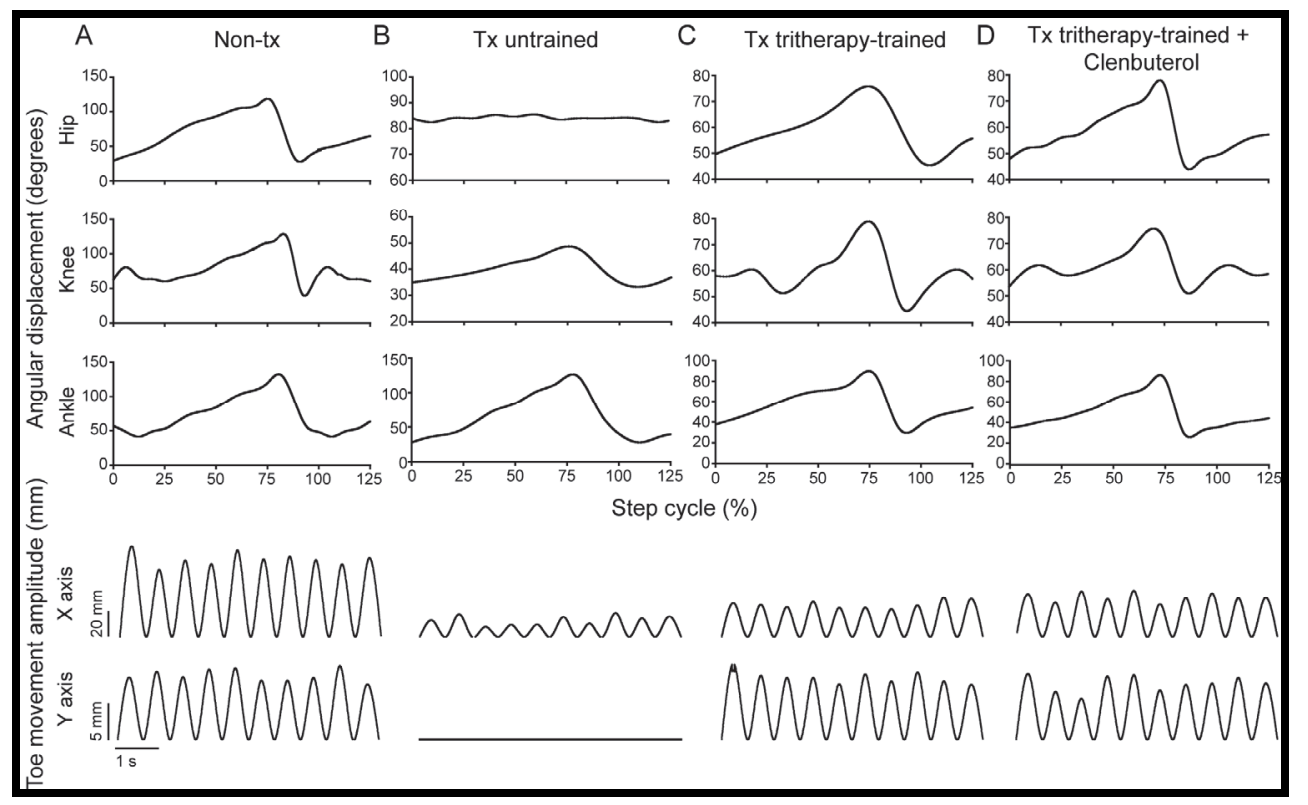

Fig. 6. Kinematic analyses in intact (non-Tx), paraplegic (Tx) untrained, paraplegic tritherapy-trained and tritherapy-trained and treated with clenbuterol. Step parameters from both tritherapy-trained paraplegic mice were similar with those from intact animals suggesting that the tritherapy appropriately restored episodes of locomotor movements. 
Femoral BMD and BMC values were measured in order to address whether tritherapytraining alone or combined with clenbuterol can prevent or at least reduce bone loss normally found in untrained paraplegic mice. However, in all groups of paraplegic animals, important losses were found. Untrained paraplegic mice (BMD: $0.0767 \pm 0.0010 \mathrm{~g} / \mathrm{cm}^{2}, \mathrm{BMC}: 0.0381 \pm$ $0.0008 \mathrm{~g}$ ) and tritherapy-trained paraplegic animals (BMD: $0.0766 \pm 0.0011 \mathrm{~g} / \mathrm{cm}^{2}, \mathrm{BMC}: 0.0378$ $\pm 0.0009 \mathrm{~g}$ ) showed comparable values whereas in paraplegic trained + clenbuterol groups, femoral BMD $(0.0731 \pm 0.0012)$ and BMC $(0.0349 \pm 0.0009)$ further decreased.

Morphometric analyses of soleus and EDL were performed in order to further characterize specific muscular property changes in all groups. Muscle CSA, fiber type-specific CSA and relative distribution values were analysed. For soleus CSA, untrained and tritherapy-trained paraplegic mice had significantly lower muscle CSA values than intact animals and tritherapy-trained + clenbuterol paraplegic groups. However soleus CSA in untrained paraplegic mice was not significantly lower than tritherapy-trained paraplegic animals. For EDL, in contrast with muscle mass changes, CSA values showed statistical differences between groups. Tritherapy-trained + clenbuterol paraplegic mice showed higher EDL CSA values than all the other groups. Untrained and tritherapy-trained paraplegic mice had lower CSA values than intact animals.

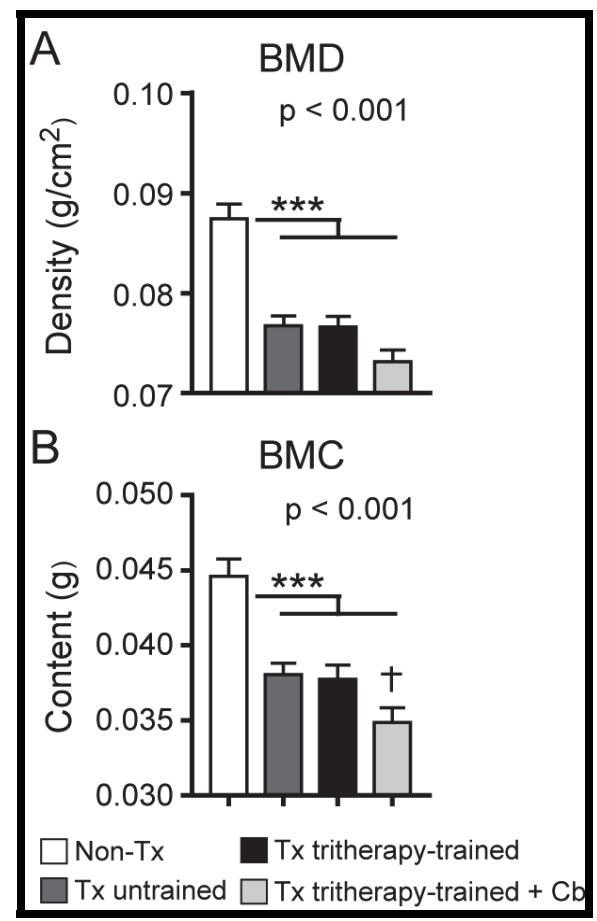

Fig. 7. Femoral BMD and BMC in intact (non-Tx), paraplegic (Tx) untrained, paraplegic tritherapy-trained and tritherapy-trained and treated with clenbuterol. Unfortunately, bone loss was not prevented in both tritherapy-trained paraplegic mice compared with intact animals suggesting that the tritherapy with or without clenbuterol failed to restore bone properties. 


\begin{tabular}{|lcccc|}
\hline \multicolumn{4}{|c|}{ Soleus and EDL muscle cross-sectional area } \\
\hline & Non-Tx & Tx untrained & $\begin{array}{c}\text { Tx tritherapy- } \\
\text { trained }\end{array}$ & $\begin{array}{c}\text { Tx tritherapy- } \\
\text { trained + clen }\end{array}$ \\
\hline Soleus & $0.85 \pm 0.05$ & $0.56 \pm 0.05^{\star *}$ & $0.64 \pm 0.04^{++}$ & $0.93 \pm 0.06$ \\
EDL & $1.10 \pm 0.04$ & $0.95 \pm 0.04^{+*}$ & $0.96 \pm 0.04^{*+}$ & $1.25 \pm 0.05^{* *}$ \\
\hline & & & & \\
\hline
\end{tabular}

Table 5. Soleus and EDL cross-sectional area values in intact (non-Tx), paraplegic (Tx) untrained, paraplegic tritherapy-trained and tritherapy-trained and treated with clenbuterol. Although encouraging anti-atrophying effects were found in tritherapy-treated paraplegic mice, only paraplegic animals that received both clenbuterol + tritherapy displayed a complete restoration of muscle size (even a relative hypertrophic effect was induced compared with intact animals).

More differences were found when analysing individually fiber type-specific CSA values. Specifically, for soleus fiber types, all three fiber types from tritherapy-trained + clenbuterol paraplegic animals displayed larger CSA values than all other groups (type I: $1656.7 \pm 80.8$ $\mu \mathrm{m}^{2}$, type II: $987.2 \pm 16.7 \mu \mathrm{m}^{2}$, hybrid: $1145.5 \pm 18.0 \mu \mathrm{m}^{2}$ ). Conversely, untrained paraplegic mice displayed the lowest soleus fiber type CSA of all groups (type I: $783.1 \pm 15.1 \mu \mathrm{m}^{2}$, type II: $753.2 \pm 9.1 \mu \mathrm{m}^{2}$, hybrid: $750.0 \pm 8.1 \mu \mathrm{m}^{2}$ ). In EDL, type II fiber CSA differences between groups were similar to soleus type II (intact: $1063.5 \pm 15.9 \mu \mathrm{m}^{2}$, paraplegic untrained: $908.1 \pm$ $11.4 \mu \mathrm{m}^{2}$, paraplegic trained: $963.4 \pm 10.9 \mu \mathrm{m}^{2}$, paraplegic trained + clenbuterol: 11.65.2 \pm $\left.17.9 \mu \mathrm{m}^{2}\right)$.

\section{Conclusion}

These findings provided proof-of-concept data strongly supporting the idea that physical activity can prevent or restore motor system adaptations normally expressed after SCI. However, that study was exploratory and thus, it remains unclear the extent to which physical activity elicited with this pharmacological approach can extensively prevent or reverse secondary complications. Although anemia and partial muscle atrophy were prevented in CPG-activating tritherapy-trained paraplegic mice, addition of anabolic aids such as clenbuterol appeared to synergistically affect positively the motor system in paraplegic mice (complete reversal of atrophy, complete lack of anemia, etc.). Effects on other elements of the motor systems such as blood vessels (e.g., deep vein size) or skeleton remain to be explored or improved. From a scientific perspective, it remains also to be determined clearly what role physical inactivity may play on motor system adaptations post-SCI and corresponding health problems in humans. This said, motor system changes post-SCI obtained in this murine model was found to resemble those typically encountered in patients with SCI or disuse. It may therefore be useful to further study basic cellular mechanisms underlying these changes of the musculoskeletal systems in these conditions. It may also serve to accelerate the development of new therapeutic strategies aimed at reducing or preventing completely all musculoskeletal and biomechanical changes in SCI patients or in patients suffering of disuse or immobilization. 


\section{References}

Siegwart, R. (2001). Indirect Manipulation of a Sphere on a Flat Disk Using Force Information. International Journal of Advanced Robotic Systems, Vol.6, No.4, (December 2009), pp. 12-16, ISSN 1729-8806

Bagi CM, Miller SC.Comparison of osteopenic changes in cancellous bone induced by ovariectomy and/or immobilization in adult rats.Anat Rec. 1994 Jul;239(3):24354.PMID:7943756

Baptiste DC, Fehlings MG (2007). Update on the treatment of spinal cord injury. Prog Brain Res, Vol 161, pp.17-33. PMID:17618980

Barbeau H, Rossignol S.The effects of serotonergic drugs on the locomotor pattern and on cutaneous reflexes of the adult chronic spinal cat.Brain Res. 1990 Apr 23;514(1):5567.PMID:2357531

Barbeau H, Rossignol S.Initiation and modulation of the locomotor pattern in the adult chronic spinal cat by noradrenergic, serotonergic and dopaminergic drugs.Brain Res. 1991 Apr 19;546(2):250-60.PMID:2070262

Barbeau H, Chau C, Rossignol S Noradrenergic agonists and locomotor training affect locomotor recovery after cord transection in adult cats. Brain Res Bull. 1993;30(34):387-93.PMID: 8457888

Barbeau H, Norman K, Fung J, Visintin M, Ladouceur M. Does neurorehabilitation play a role in the recovery of walking in neurological populations? Ann N Y Acad Sci. 1998 Nov 16;860:377-92. Review. PMID: 9928326

Bauman WA, Spungen AM, Adkins RH, Kemp BJ.Metabolic and endocrine changes in persons aging with spinal cord injury.Assist Technol. 1999;11(2):88-96. Review.PMID:11010069

Brown TG. On the nature of the fundamental activity of the nervous centres; together with an analysis of the conditioning of rhythmic activity in progression, and a theory of the evolution of function in the nervous system.J Physiol. 1914 Mar 31;48(1):18-46 PMID: 16993247

Cazalets JR, Sqalli-Houssaini Y, Clarac F.Activation of the central pattern generators for locomotion by serotonin and excitatory amino acids in neonatal rat.J Physiol. 1992 Sep;455:187-204.PMID:1362441

Chau C, Barbeau H, Rossignol S.Early locomotor training with clonidine in spinal cats.J Neurophysiol. 1998 Jan;79(1):392-409.PMID:9425208

Cina C, Hochman S.Diffuse distribution of sulforhodamine-labeled neurons during serotonin-evoked locomotion in the neonatal rat thoracolumbar spinal cord.J Comp Neurol. 2000 Aug 7;423(4):590-602.PMID:10880990

Côté $\mathrm{CH}$, Perreault G, Frenette J.Carbohydrate utilization in rat soleus muscle is influenced by carbonic anhydrase III activity.Am J Physiol. 1997 Oct;273(4 Pt 2):R12118.PMID:9362282

Davey DF, Dunlop C, Hoh JF, Wong SY.Contractile properties and ultrastructure of extensor digitorum longus and soleus muscles in spinal cord transected rats.Aust J Exp Biol Med Sci. 1981 Aug;59(4):393-404.PMID:7295218

Deep K, Jigajinni MV, McLean AN, Fraser MH.Prophylaxis of thromboembolism in spinal injuries--results of enoxaparin used in 276 patients.Spinal Cord. 2001 Feb;39(2):8891.PMID:11402364 
DeVivo MJ, Jackson AB, Dijkers MP, Becker BE.Current research outcomes from the Model Spinal Cord Injury Care Systems.Arch Phys Med Rehabil. 1999 Nov;80(11):1363-4. No abstract available. PMID:10569428

Dimitrijevic MR, Gerasimenko Y, Pinter MM.Evidence for a spinal central pattern generator in humans.Ann N Y Acad Sci. 1998 Nov 16;860:360-76.PMID:9928325

Dobkin B, Apple D, Barbeau H, Basso M, Behrman A, Deforge D, Ditunno J, Dudley G, Elashoff R, Fugate L, Harkema S, Saulino M, Scott M; Spinal Cord Injury Locomotor Trial Group.Weight-supported treadmill vs over-ground training for walking after acute incomplete SCI.Neurology. 2006 Feb 28;66(4):48493.PMID:16505299

Duffell LD, de N Donaldson N, Newham DJ. Why is the metabolic efficiency of FES cycling low? IEEE Trans Neural Syst Rehabil Eng. 2009 Jun;17(3):263-9. Epub 2009 Feb 27. Erratum in: IEEE Trans Neural Syst Rehabil Eng. 2009 Dec;17(6):605. PMID:19258202

Dupont-Versteegden EE, Murphy RJ, Houlé JD, Gurley CM, Peterson CA.Mechanisms leading to restoration of muscle size with exercise and transplantation after spinal cord injury.Am J Physiol Cell Physiol. 2000 Dec;279(6):C1677-84.PMID:11078681

Fitts RH, Riley DR, Widrick JJ.Functional and structural adaptations of skeletal muscle to microgravity.J Exp Biol. 2001 Sep;204(Pt 18):3201-8. Review.PMID:11581335

Frenette J, St-Pierre M, Côté CH, Mylona E, Pizza FX.Muscle impairment occurs rapidly and precedes inflammatory cell accumulation after mechanical loading.Am J Physiol Regul Integr Comp Physiol. 2002 Feb;282(2):R351-7.PMID:11792643

Frisbie JH.An animal model for venous thrombosis and spontaneous pulmonary embolism.Spinal Cord. 2005 Nov;43(11):635-9.PMID:15951743

Garland DE, Stewart CA, Adkins RH, Hu SS, Rosen C, Liotta FJ, Weinstein DA.Osteoporosis after spinal cord injury.J Orthop Res. 1992 May;10(3):371-8.PMID:1569500

Green D, Hartwig D, Chen D, Soltysik RC, Yarnold PR.Spinal Cord Injury Risk Assessment for Thromboembolism (SPIRATE Study).Am J Phys Med Rehabil. 2003 Dec;82(12):950-6.PMID:14627932

Grillner S, Zangger P.On the central generation of locomotion in the low spinal cat.Exp Brain Res. 1979 Jan 15;34(2):241-61.PMID:421750

Grossman EJ, Roy RR, Talmadge RJ, Zhong H, Edgerton VR.Effects of inactivity on myosin heavy chain composition and size of rat soleus fibers.Muscle Nerve. 1998 Mar;21(3):375-89.PMID:9486867

Guertin PA.The mammalian central pattern generator for locomotion.Brain Res Rev. 2009 Dec 11;62(1):45-56. Epub 2009 Aug 29. Review.PMID:19720083

Guertin PA, Ung RV, Rouleau P.Oral administration of a tri-therapy for central pattern generator activation in paraplegic mice: proof-of-concept of efficacy.Biotechnol J. 2010 Apr;5(4):421-6.PMID:20349462

Guertin PA, Ung RV, Rouleau P, Steuer I.Effects on locomotion, muscle, bone, and blood induced by a combination therapy eliciting weight-bearing stepping in nonassisted spinal cord-transected mice.Neurorehabil Neural Repair. 2011 Mar;25(3):234-42. Epub 2010 Oct 15.PMID:20952632

Hanson AM, Ferguson VL, Simske SJ, Cannon CM, Stodieck S.Comparison of tailsuspension and sciatic nerve crush on the musculoskeletal system in young-adult mice. Biomed Sci Instrum. 2005;41:92-6.PMID:15850088 
Hicks AL, Ginis KA.Treadmill training after spinal cord injury: it's not just about the walking.J Rehabil Res Dev. 2008;45(2):241-8. Review.PMID:18566942

Huang CT, DeVivo MJ, Stover SL.Anemia in acute phase of spinal cord injury.Arch Phys Med Rehabil. 1990 Jan;71(1):3-7. PMID:2297306

Ito T, Ohmori S, Kanda K, Kawano S, Murata Y, Seo H.Changes in serum 1,25dihydroxyvitamin D3 and mRNAs for osteocalcin and alkaline phosphatase in femur unloaded by tail suspension in rats.Environ Med. 1994;38(2):1036.PMID:12703522

Kjaerulff O, Barajon I, Kiehn O.Sulphorhodamine-labelled cells in the neonatal rat spinal cord following chemically induced locomotor activity in vitro.J Physiol. 1994 Jul 15;478 ( Pt 2):265-73.PMID:7525942

Koh TJ, Brooks SV.Lengthening contractions are not required to induce protection from contraction-induced muscle injury.Am J Physiol Regul Integr Comp Physiol. 2001 Jul;281(1):R155-61.PMID:11404289

Krikorian JG, Guth L, Barrett CP, Donati EJ.Enzyme histochemical changes after transection or hemisection of the spinal cord of the rat.Exp Neurol. 1982 Jun;76(3):623-43. PMID:6211367

Lainscak M, Podbregar M, Anker SD (December 2007). "How does cachexia influence survival in cancer, heart failure and other chronic diseases?". Curr Opin Support Palliat Care 1 (4): 299-305. PMID 18685379

Landry E, Frenette J, Guertin PA.Body weight, limb size, and muscular properties of early paraplegic mice.J Neurotrauma. 2004 Aug;21(8):1008-16.PMID:15319000

Landry ES, Rouillard C, Levesque D, Guertin PA.Profile of immediate early gene expression in the lumbar spinal cord of low-thoracic paraplegic mice.Behav Neurosci. 2006 Dec;120(6):1384-8.PMID:17201484

Landry ES, Lapointe NP, Rouillard C, Levesque D, Hedlund PB, Guertin PA.Contribution of spinal 5-HT1A and 5-HT7 receptors to locomotor-like movement induced by 8-OHDPAT in spinal cord-transected mice.Eur J Neurosci. 2006 Jul;24(2):535-46. Epub 2006 Jul 12.PMID:16836640

Lazo MG, Shirazi P, Sam M, Giobbie-Hurder A, Blacconiere MJ, Muppidi M.Osteoporosis and risk of fracture in men with spinal cord injury.Spinal Cord. 2001 Apr;39(4):20814.PMID:11420736

Lieber RL, Johansson CB, Vahlsing HL, Hargens AR, Feringa ER.Long-term effects of spinal cord transection on fast and slow rat skeletal muscle. I. Contractile properties.Exp Neurol. 1986 Mar;91(3):423-34.PMID:3948953

Lieber RL, Fridén JO, Hargens AR, Feringa ER.Long-term effects of spinal cord transection on fast and slow rat skeletal muscle. II. Morphometric properties.Exp Neurol. 1986 Mar;91(3):435-48.PMID:2936616

Ma YF, Jee WS, Ke HZ, Lin BY, Liang XG, Li M, Yamamoto N.Human parathyroid hormone-(1-38) restores cancellous bone to the immobilized, osteopenic proximal tibial metaphysis in rats.J Bone Miner Res. 1995 Mar;10(3):496-505.PMID:7785472

Midrio M, Danieli Betto D, Betto R, Noventa D, Antico F.Cordotomy-denervation interactions on contractile and myofibrillar properties of fast and slow muscles in the rat.Exp Neurol. 1988 Apr;100(1):216-36.PMID:3350090 
Mosekilde L, Thomsen JS, Mackey MS, Phipps RJ.Treatment with risedronate or alendronate prevents hind-limb immobilization-induced loss of bone density and strength in adult female rats.Bone. 2000 Nov;27(5):639-45.PMID:11062350

Nishimaru H, Takizawa H, Kudo N.5-Hydroxytryptamine-induced locomotor rhythm in the neonatal mouse spinal cord in vitro.Neurosci Lett. 2000 Feb 25;280(3):18790.PMID:10675792

Picard S, Lapointe NP, Brown JP, Guertin PA.Histomorphometric and densitometric changes in the femora of spinal cord transected mice.Anat Rec (Hoboken). 2008 Mar;291(3):303-7.PMID:18231968

Rémy-Néris O, Denys P, Daniel O, Barbeau H, Bussel B.Effect of intrathecal clonidine on group I and group II oligosynaptic excitation in paraplegics.Exp Brain Res. 2003 Feb;148(4):509-14. Epub 2002 Nov 22.PMID: 2582835

Ragnarsson KT, Sell GH.Lower extremity fractures after spinal cord injury: a retrospective study.Arch Phys Med Rehabil. 1981 Sep;62(9):418-23.PMID:7283682

Rantakokko J, Uusitalo H, Jämsä T, Tuukkanen J, Aro HT, Vuorio E.Expression profiles of mRNAs for osteoblast and osteoclast proteins as indicators of bone loss in mouse immobilization osteopenia model.J Bone Miner Res. 1999 Nov;14(11):193442.PMID:10571694

Reeve Foundation at www.christopherreeve.com.

Riegger T, Conrad S, Liu K, Schluesener HJ, Adibzahdeh M, Schwab JM.Spinal cord injuryinduced immune depression syndrome (SCI-IDS).Eur J Neurosci. 2007 Mar; 25(6):1743-7.PMID:17432962

Rossignol S, Dubuc R.Spinal pattern generation.Curr Opin Neurobiol. 1994 Dec;4(6):894-902. Review.PMID:7888774

Rouleau P, Guertin PA.Traumatic and non-traumatic spinal cord-injured patients in Quebec, Canada. Part 2: biochemical profile.Spinal Cord. 2010 Nov;48(11):819-24. Epub 2010 May 11.PMID:20458326

Rouleau P, Guertin PA.Traumatic and nontraumatic spinal-cord-injured patients in Quebec, Canada. Part 3: pharmacological characteristics.Spinal Cord. 2011 Feb;49(2):186-95. Epub 2010 Jun 15.PMID:20548322

Rouleau P, Ung RV, Lapointe NP, Guertin PA.Hormonal and immunological changes in mice after spinal cord injury.J Neurotrauma. 2007 Feb;24(2):367-78.PMID:17376000

Rouleau P, Guertin PA Early changes in deep vein diameter and biochemical markers associated with thrombi formation after spinal cord injury in mice.J Neurotrauma. 2007 Aug;24(8):1406-14. PMID:17711402

Roy RR, Baldwin KM, Edgerton VR.The plasticity of skeletal muscle: effects of neuromuscular activity.Exerc Sport Sci Rev. 1991;19:269-312. Review.PMID:1936088

Sabo D, Blaich S, Wenz W, Hohmann M, Loew M, Gerner HJ.Osteoporosis in patients with paralysis after spinal cord injury. A cross sectional study in 46 male patients with dual-energy X-ray absorptiometry.Arch Orthop Trauma Surg. 2001;121(1-2):758.PMID:11195125

Sherrington CS.Flexion-reflex of the limb, crossed extension-reflex, and reflex stepping and standing.J Physiol. 1910 Apr 26;40(1-2):28-121.PMID:1699302

Spungen AM, Adkins RH, Stewart CA, Wang J, Pierson RN Jr, Waters RL, Bauman WA.Factors influencing body composition in persons with spinal cord injury: a 
cross-sectional study.J Appl Physiol. 2003 Dec;95(6):2398-407. Epub 2003 Aug 8.PMID:12909613

Talmadge RJ, Roy RR, Edgerton VR.Prominence of myosin heavy chain hybrid fibers in soleus muscle of spinal cord-transected rats.J Appl Physiol. 1995 Apr;78(4):125665.PMID:7615431

Talmadge RJ, Roy RR, Edgerton VR.Persistence of hybrid fibers in rat soleus after spinal cord transection.Anat Rec. 1999 Jun 1;255(2):188-201.PMID:10359520

Talmadge RJ, Roy RR, Caiozzo VJ, Edgerton VR Mechanical properties of rat soleus after long-term spinal cord transection.J Appl Physiol. 2002 Oct;93(4):148797.PMID:12235051

Thomason DB, Herrick RE, Surdyka D, Baldwin KM. Time course of soleus muscle myosin expression during hindlimb suspension and recovery.J Appl Physiol. 1987 Jul;63(1):130-7.PMID:2957349

Ung RV, Landry ES, Rouleau P, Lapointe NP, Rouillard C, Guertin PA.Role of spinal 5-HT2 receptor subtypes in quipazine-induced hindlimb movements after a low-thoracic spinal cord transection.Eur J Neurosci. 2008 Dec;28(11):2231-42. Epub 2008 Nov 3.PMID:19019202

Viala D, Buser P. Methods of obtaining locomotor rhythms in the spinal rabbit by pharmacological treatments (DOPA, 5-HTP, D-amphetamine)].Brain Res. 1971 Dec 10;35(1):151-65.[PMID: 5289621

Wainberg M, Barbeau H, Gauthier S.The effects of cyproheptadine on locomotion and on spasticity in patients with spinal cord injuries.J Neurol Neurosurg Psychiatry. 1990 Sep;53(9):754-63.PMID: 2246657

Waring WP, Karunas RS.Acute spinal cord injuries and the incidence of clinically occurring thromboembolic disease.Paraplegia. 1991 Jan;29(1):8-16.PMID:2023773

Wilmet E, Ismail AA, Heilporn A, Welraeds D, Bergmann P.Longitudinal study of the bone mineral content and of soft tissue composition after spinal cord section.Paraplegia. 1995 Nov;33(11):674-7.PMID:8584304

Wronski TJ, Dann LM, Scott KS, Crooke LR Endocrine and pharmacological suppressors of bone turnover protect against osteopenia in ovariectomized rats.Endocrinology. 1989 Aug;125(2):810-6.PMID : 2502377

Zeng QQ, Jee WS, Bigornia AE, King JG Jr, D'Souza SM, Li XJ, Ma YF, Wechter WJ.Time responses of cancellous and cortical bones to sciatic neurectomy in growing female rats.Bone. 1996 Jul;19(1):13-21.PMID:8830982 


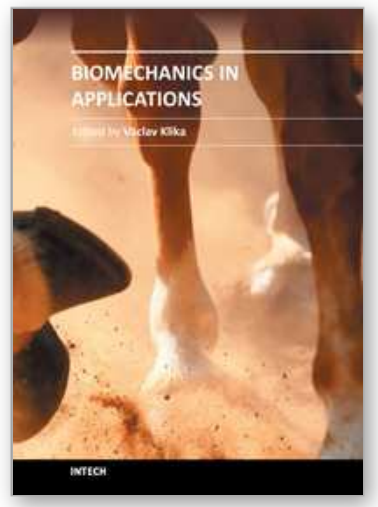

\author{
Biomechanics in Applications \\ Edited by Dr Vaclav Klika
}

ISBN 978-953-307-969-1

Hard cover, 408 pages

Publisher InTech

Published online 09, September, 2011

Published in print edition September, 2011

During last couple of years there has been an increasing recognition that problems arising in biology or related to medicine really need a multidisciplinary approach. For this reason some special branches of both applied theoretical physics and mathematics have recently emerged such as biomechanics, mechanobiology, mathematical biology, biothermodynamics. The Biomechanics in Application is focusing on experimental praxis and clinical findings. The first section is devoted to Injury and clinical biomechanics including overview of the biomechanics of musculoskeletal injury, distraction osteogenesis in mandible, or consequences of drilling. The next section is on Spine biomechanics with biomechanical models for upper limb after spinal cord injury and an animal model looking at changes occurring as a consequence of spinal cord injury. Section Musculoskeletal Biomechanics includes the chapter which is devoted to dynamical stability of lumbo-pelvi-femoral complex which involves analysis of relationship among appropriate anatomical structures in this region. The fourth section is on Human and Animal Biomechanics with contributions from foot biomechanics and chewing rhythms in mammals, or adaptations of bats. The last section, Sport Biomechanics, is discussing various measurement techniques for assessment and analysis of movement and two applications in swimming.

\title{
How to reference
}

In order to correctly reference this scholarly work, feel free to copy and paste the following:

Pierre A. Guertin (2011). Adaptations of the Motor System in Animal Models of Spinal Cord Injury and Disuse, Biomechanics in Applications, Dr Vaclav Klika (Ed.), ISBN: 978-953-307-969-1, InTech, Available from: http://www.intechopen.com/books/biomechanics-in-applications/adaptations-of-the-motor-system-in-animalmodels-of-spinal-cord-injury-and-disuse

\section{INTECH}

open science | open minds

\section{InTech Europe}

University Campus STeP Ri

Slavka Krautzeka 83/A

51000 Rijeka, Croatia

Phone: +385 (51) 770447

Fax: +385 (51) 686166

www.intechopen.com

\section{InTech China}

Unit 405, Office Block, Hotel Equatorial Shanghai

No.65, Yan An Road (West), Shanghai, 200040, China

中国上海市延安西路65号上海国际贵都大饭店办公楼405单元

Phone: +86-21-62489820

Fax: $+86-21-62489821$ 
(C) 2011 The Author(s). Licensee IntechOpen. This chapter is distributed under the terms of the Creative Commons Attribution-NonCommercialShareAlike-3.0 License, which permits use, distribution and reproduction for non-commercial purposes, provided the original is properly cited and derivative works building on this content are distributed under the same license. 